\title{
Nitric oxide and cancer: a review
}

\author{
Sheetal Korde Choudhari ${ }^{1 *}$, Minal Chaudhary², Sachin Bagde ${ }^{3}$, Amol R Gadbail $^{2}$ and Vaishali Joshi ${ }^{1}$
}

\begin{abstract}
Nitric oxide (NO), is a ubiquitous, water soluble, free radical gas, which plays key role in various physiological as well as pathological processes. Over past decades, NO has emerged as a molecule of interest in carcinogenesis and tumor growth progression. However, there is considerable controversy and confusion in understanding its role in cancer biology. It is said to have both tumoricidal as well as tumor promoting effects which depend on its timing, location, and concentration. NO has been suggested to modulate different cancer-related events including angiogenesis, apoptosis, cell cycle, invasion, and metastasis. On the other hand, it is also emerging as a potential anti-oncogenic agent. Strategies for manipulating in vivo production and exogenous delivery of this molecule for therapeutic gain are being investigated. However, further validation and experimental/clinical trials are required for development of novel strategies based on NO for cancer treatment and prevention. This review discusses the range of actions of NO in cancer by performing an online MEDLINE search using relevant search terms and a review of the literature. Various mechanisms by which NO acts in different cancers such as breast, cervical, gastric,colorectal, and head and neck cancers are addressed. It also offers an insight into the dichotomous nature of $\mathrm{NO}$ and discusses its novel therapeutic applications for cancer prevention and treatment.
\end{abstract}

Keywords: Breast cancer, Gastric cancer, Lung cancer, Head and Neck cancer, H. Pylori, Human papillomavirus, Nitric oxide, Nitric oxide synthase

\section{Review}

Introduction

Nitric oxide (NO) is a short-lived, endogenously produced gas that acts as a signaling molecule in the body. Ignarro et al. and Palmer et al. simultaneously identified $\mathrm{NO}$ as the endothelium-derived relaxing factor in 1987 $[1,2]$. It is synthesized by nitric oxide synthase (NOS) enzymes; produced by mammalian cells at an appropriate magnitude and tempo, it serves as a key signaling molecule in various physiological processes. On the other hand, excessive and unregulated NO synthesis has been implicated as causal or contributing to pathophysiological conditions including cancer. Expression of NOS has been detected in various cancers such as cervical, breast, central nervous system, laryngeal, and head and neck cancers [3-7]. NO has been suggested to modulate different cancer-related events [8]. However, several lines of research have indicated that NO may have dual effects in cancer. At concentrations measurable in many

\footnotetext{
* Correspondence: kordesheetal@yahoo.co.in

'Department of Oral Pathology \& Microbiology, Yerala Dental College and Hospital, Institutional Area, Sector 4, Kharghar, Navi Mumbai, Maharashtra 410 210, India

Full list of author information is available at the end of the article
}

different types of clinical samples, NO seems to promote tumor growth and proliferation. In contrast to this, NO is said to have tumoricidal effects;various direct and indirect mechanisms have been proposed for its antitumor properties $[9,10]$, although there is lack of data directly on cancer patients. Nevertheless, the tumoricidal properties of NO are being investigated for therapeutic purposes. NO is used alone or in combination with other cytotoxic agents. In order to obtain a better insight into the dichotomous nature of $\mathrm{NO}$, an online search using proper search terms through MEDLINE was undertaken and the relevant literature was reviewed. This review discusses the diverse actions of NO in cancer and NO's novel applications in cancer treatment and prevention.

\section{Biological and physiological aspects of NO}

$\mathrm{NO}$, a short-lived endogenously produced gas, is synthesized by a complex family of NOS enzymes. Mammalian cells are endowed with three genes encoding distinct isoforms of NOS- NOS1, NOS2, and NOS3 -with 51$57 \%$ homology between isoforms and different localizations, regulation, catalytic properties, and inhibitor sensitivity. NOS1, also known as nNOS (isoform first
C Biomed Central

(c) 2013 Korde Choudhari et al.; licensee BioMed Central Ltd. This is an Open Access article distributed under the terms of the Creative Commons Attribution License (http://creativecommons.org/licenses/by/2.0), which permits unrestricted use,

distribution, and reproduction in any medium, provided the original work is properly cited. 
purified and cloned from neuronal tissue), and NOS3 or eNOS (isoform first found in endothelial cells) are also termed as constitutive since they are expressed continuously in neurons and endothelial cells, respectively. They are also dependent on a rise in tissue calcium concentration for activity and therefore produce low, transient concentrations of NO. In contrast, NOS2 is an inducible, calcium-independent isoform, also called iNOS. Unlike NOS1 and NOS3, induction of NOS2 results in continuous production of NO [11]. It is inducible by immunological stimuli in virtually all nucleated mammalian cells. Once induced, the enzyme continues to produce much higher NO concentrations for many hours or even days. An important regulator of NOS2 is the tumor suppressor gene p53 which senses raised cellular $\mathrm{NO}$ and inhibits NOS2 by a negative feedback loop [12]. This relationship has important implications in cancer.

Contrary to conventional biosignaling molecules that act by binding to specific receptor molecules, NO manifests its biological actions via a wide range of chemical reactions. The precise reactions depend on the concentration of $\mathrm{NO}$ achieved and on subtle variations in the composition of intra- and extracellular milieu [11]. Under normal physiological conditions, cells produce small but significant amounts of NO which contribute to regulation of anti-inflammatory effects and its antioxidant properties $[13,14]$. However, in tissues with a high-output of NO, iNOSisupregulated and effects such as nitration (addition of $\mathrm{NO}_{2}$ ), nitrosation (addition of $\mathrm{NO}^{+}$), and oxidation will prevail [13]. Interaction of $\mathrm{NO}$ with $\mathrm{O}_{2}$ or $\mathrm{O}_{2}^{-}$results in formation of reactive nitrogen species (RNS). The RNS, dinitrogen trioxide $\left(\mathrm{N}_{2} \mathrm{O}_{3}\right)$ and peroxynitrite (ONOO), can induce two types of chemical stresses,nitrosative and oxidative [15]. $\mathrm{N}_{2} \mathrm{O}_{3}$ is a potent nitrosating agent which has been shown to $\mathrm{N}$ - and S- nitrosate a variety of biological targets to yield potentially carcinogenic nitrosamines and nitrosothiol derivatives. N-nitrosation may have important implications in the known association between chronic inflammation and malignant transformation $[15,16] . \mathrm{O}_{2}^{-}$and $\mathrm{NO}$ may rapidly interact to produce the potent cytotoxic oxidants peroxynitrite $\left(\mathrm{ONOO}^{-}\right)$and its conjugate acid $\mathrm{ONOOH}$. Peroxynitrite in natural solution is a powerful oxidant, oxidizing thiols or thioethers, nitrating tyrosine residues, nitrating and oxidizing guanosine, degrading carbohydrates, initiating lipid peroxidation and cleaving DNA, which has important implications in cancer $[17,18]$.

\section{Diverse actions of NO in cancer}

NO has been reported to exert dichotomous effects within the multistage model of cancer (Tables 1 and 2). It modulates different cancer-related events including angiogenesis, apoptosis, cell cycle, invasion, and metastasis [8] (Table 1). In contrast to tumor promoting effects,
Table 1 Diverse actions of NO in cancer: tumor promoting role of NO

\begin{tabular}{|c|c|}
\hline \multicolumn{2}{|c|}{ Tumor promoting role } \\
\hline Role of nitric oxide (NO) & Mechanism by which NO acts \\
\hline \multirow[t]{3}{*}{ Genotoxicmechanisms } & $\begin{array}{l}\text { Formation of toxic and mutagenic } \\
\text { species }\end{array}$ \\
\hline & $\begin{array}{l}\text { Direct modification of DNA- strand } \\
\text { breaks, oxidation and deamination of } \\
\text { nucleic acids }\end{array}$ \\
\hline & $\begin{array}{l}\text { Inhibition of systems required to repair } \\
\text { DNA lesions }\end{array}$ \\
\hline \multirow[t]{6}{*}{ Antiapoptotic effects } & $\begin{array}{l}\text { GC to AT mutations in p53- loss of its } \\
\text { repressor activity }\end{array}$ \\
\hline & $\begin{array}{l}\text { Direct inhibition of caspase activity } \\
\text { through s-nitrosylation of the cysteine } \\
\text { thiol }\end{array}$ \\
\hline & Inhibition of cytochrome $\mathrm{C}$ release \\
\hline & Increase in $\mathrm{Bcl}-2$ expression \\
\hline & Suppression of ceramide generation \\
\hline & Activation of cyclooxygenase \\
\hline
\end{tabular}

Induces and promotes angiogenesis (iNOSandeNOS)

Dilatation of arteriolar vessels by eNOS

VEGF release and NO stimulation of hyperpermeability of vascular endothelium

Increased production of PGE2 resulting in increased tumor vasculature permeability

Activation of COX-2 which stimulates production of proangiogenic factors and prostaglandins

Limits host immune response against tumor

Suppression of proliferation and infiltration of leukocytes

Low leukocyte-endothelial interaction

Promotes metastasis Promotes lymphangiogenesis and spread to lymph nodes possibly through involvement of VEGF-C

Upregulation of MMP-2 and -9

Downregulation of TIMP-2 and-3

NO has also been reported to have tumoricidal effects (Table 2). Understanding its role in tumor biology will help in reducing the controversy and confusion and will help in developing novel NO based therapies which will prove helpful in preventing and treating various human cancers.

The effects of NO in tumor biology are broad, spanning its involvement in cellular transformation, formation of neoplastic lesions, and initiation and regulation of the metastatic cascade. NO participates in genotoxic events $[19,20]$. It may mediate DNA lesions by formation of toxic and mutagenic species, by direct modification of DNA, or by inhibition of DNA repair mechanisms [21]. RNS can mediate DNA strand breaks and can also yield different types of mutations in DNA [22,23]. NO 
Table 2 Diverse actions of NO in cancer: tumoricidal role of NO

\begin{tabular}{ll}
\hline Tumoricidal role \\
\hline Role of NO & Mechanism by which NO acts \\
\hline $\begin{array}{l}\text { Cytostatic andlor cytotoxic } \\
\text { effect on tumor cells }\end{array}$ & NO suppresses cellular respiration and \\
& also shifts iron metabolism \\
& Suppression of DNA synthesis \\
& $\begin{array}{l}\text { Proapoptotic modulator by activating } \\
\text { caspase family proteases, upregulation of } \\
\text { p53, alteration in expression of } \\
\text { apoptosis-associated proteins }\end{array}$ \\
\hline
\end{tabular}

production via iNOS may directly induce GC to AT mutations in p53 which may contribute to loss of its repressor activity. NO directly inhibits activity of caspases providing an efficient means to block apoptosis. Other antiapoptotic effects of NO rely on NO/cGMP dependent inhibition of cytochrome $\mathrm{C}$ release, increase in $\mathrm{Bcl}-2$ expression that controls the mitochondrial permeability transition pore, induction of heat-shock protein (Hsp) 70 and Hsp 32, suppression of ceramide generation [24], and activation of cyclooxygenase-2 [24,25]. NO plays an important role in tumor progression by regulation of angiogenesis. Endogenous NO promotes tumor blood flow via dilatation of arteriolar vessels. It decreases leukocyte endothelial adhesive interactions and increases vascular permeability [26]. Studies have shown that VEGF released as a purified protein or produced by tumor cells requires a functional $\mathrm{NO} /$ cGMP pathway within the end compartment to promote neovascular growth. Another mechanism by which $\mathrm{NO}$ promotes angiogenesis is by activation of COX-2 which stimulates the production of proangiogenic factors and prostaglandins. $\mathrm{NO}$ also has an invasion stimulating effect which is mediated by upregulation of MMP-2 and MMP-9 (matrix metalloproteinases), and downregulation of TIMP-2 and possibly TIMP-3 (tissue inhibitors of MMP) [27]. Studies have indicated that NO limits leukocyte cell proliferation which has adverse consequences on the antitumor response of the host [23]. In this way NO may be involved in the growth and spread of tumors (Figure 1).

\section{NO in various human cancers}

Nitric oxide seems to play diverse roles in various human cancers [3-7]. Understanding different actions of $\mathrm{NO}$ in these cancers at the molecular level can help in providing NO based diagnostic or prognostic markers and also in devising potential strategies for prevention and treatment of these cancers.

\section{NO and breast cancer}

Breast cancer is currently the most common cancer in women worldwide, both in developed and developing countries [28]. NOhas been investigatedregarding its possible involvement in the promotion of breast carcinoma. Specific expression of NOS has been reported in breast cancer tissues [29] and in breast carcinoma cell lines [30]. Increased amounts of NO have been observed in blood of breast cancer patients [31] and higher NOS activity has been found in invasive breast tumors when compared with benign or normal breast tissue [29]. Authors have found a high rate of NOS in in situcarcinoma [29]. Furthermore, NOS activity has been found to be higher in advanced grades of breast carcinomas [31]. All these findings suggest that NOS expression in breast cancer may be an early event in carcinogenesis.

$\mathrm{NO}$ is reported to have several important effects in the control of neoplasms. Jadeskiet al. suggested that the presence of eNOS in breast apocrine metaplastic cells of fibrocystic disease in the human may promote the progression of metaplastic epithelium into carcinoma [32].

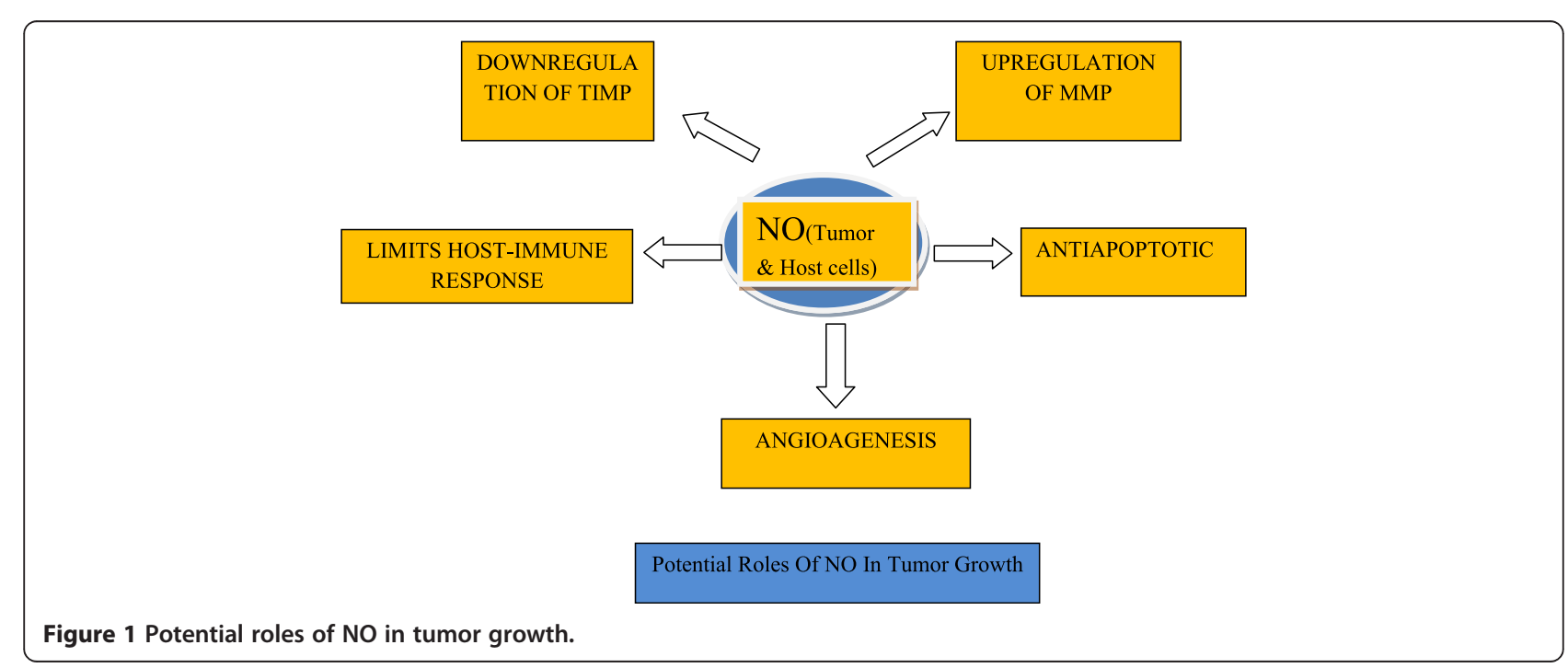


NO increases tumor blood flow and promotes angiogenesis, which could explain the positive correlation between NO biosynthesis and grade of malignancy [31]. Nitrotyrosine, a biomarker of NO, was found to be correlated with VEGF-C expression and lymph node metastasis in breast cancer suggesting the role of $\mathrm{NO}$ in progression of breast carcinoma [33]. Switzer et al. showed that NOS2 expression in human breast tumors is functionally linked to poor patient survival [34].

\section{$\mathrm{NO}$ and hormones in breast cancer}

Unlike other types of cancer, tumors of the breast are greatly influenced by steroid hormones. Recent findings implicate NO pathway in some of their effects. Estrogen and progesteronecan regulate NOS and, in turn, the NO produced has profound consequences on tumor cell homeostasis $[30,35]$. It has been found that estrogen stimulates eNOS release in breast tissue [36] where it acts as a free radical. eNOS expression has been found to be strongly correlated with estrogen receptor expression in a human breast cancer cell line, suggesting free radicals as possible causes of breast cancer [36]. Progesterone has been found to activate iNOS expression. It has been suggested that the low levels of NO produced by eNOS mediate the proliferative effect of estrogen [37]. On the other hand, an increase in apoptosis in response to progesterone could implicate high levels of NO produced by induction of iNOS expression [37]. Thus an understanding of the mechanisms and interactions of steroid hormones with the NO pathway could lead to the development of new approaches and strategies for the effective treatment of breast cancer.

\section{$\mathrm{NO}$ and cervical cancer}

Cervical cancer is the second most common cancer in women worldwide, with $>200,000$ deaths annually [38]. Epidemiological studies have revealed a number of risk factors, including smoking, multiparity, long-term use of oral contraceptives, chronic inflammation, and other sexually transmitted infections (e.g., chlamydia trachomatis and herpes simplex virus type 2) [39]. Interestingly, these cofactors all increaseNO levels in the cervical microenvironment [40-42]. Significantly higher levels of NO were observed in serum of patients with cervical cancer as compared to healthy controls $[43,44]$. Increased NO levels and markers of NO-mediated mutagenesis have been observed in the cervixes of women with cervical intraepithelial neoplasia $[45,46]$. All these findings suggest that NO has potential mutagenic and carcinogenic activity in cervical cancer.

\section{Human papillomaviruses, NO and cervical cancer}

Infections with any of the 15 types of human papillomaviruses (HPV) cause virtually all cases of cervical and other anogenital cancers [47]. According to Wei et al., $\mathrm{NO}$ acts as a molecular cofactor with HPV infection in cervical carcinogenesis [48]. Wei et al. found that the presence of HR-HPV is associated with an increased release of NO in the human uterine cervix [49] and that physiological doses of NO could promote malignant progression of HPV-infected cells in vivo. According to them, various epidemiologically defined cofactors for cervical cancer increase NO levels in the cervical microenvironment [48]. This increase in NO causes earlier mRNA expression, decreased pRb and p53 levels, low p53 activity, and apoptotic indices in HPV-infected cells in the cervix, resulting in increased survival of mutant cells leading to carcinogenesis [48].

\section{NO and lung cancer}

Tobacco smoke is the main cause for lung cancer $[50,51]$. It leads to chronic airway inflammation with accumulation and activation of leukocytes which produce high levels of ROS and NO [52]. It has been demonstrated that NO, nitrite, and nitrotyrosine are increased in patients with lung cancer [49]. Chen et al. found significantly higher levels of iNOS/NO in lung cancer tissues of smokers than that of non-smokers [53]. Strong immunoreactivity for iNOS and eNOS was observed in dysplastic lesions in the lung [54]. Certain hexavalent chromium $[\mathrm{Cr}(\mathrm{VI})]$ compounds have been postulated to play a significant role in pulmonary tumorigenesis. Forbes et al.concluded that repetitive exposure to particulate chromate induces an inflammatory environment in the lung, accompanied by enhanced NO production, which may promote lung carcinogenesis [55].

$\mathrm{NO}$ may contribute to lung carcinogenesis by nitration of proteins. $\mathrm{NO}$ and its metabolites interact with ROS to generate potent nitrating agents leading to 3-nitrotyrosine formation in proteins $[56,57]$, which is one of several chemical modifications that occur during oxidative/nitrosative stress $[57,58]$. At high levels, NO inactivates p53 [59] and p53 inactivation by nitration could also contribute to carcinogenesis given that over $90 \%$ of lung tumors are with defective p53 [52]. With broad effects on angiogenesis, glycolysis, p53 activity, antioxidant potential in the lung, and alteration of cell growth pathways, NO may create a microenvironment that promotestumorigenesis and/or promotes tumor heterogeneity leading to metastasis [52]. The prognosis of lung cancer is still poor because of the absence of valid approaches to its early detection. Exhaled breath analysis and exhaled NO measurements may provide useful assays in predicting diagnosis and disease progression [60].

\section{NO in gastric cancer}

Despite advances in surgical treatment and chemotherapy, gastric cancer remains a major global health burden; various etiologic factors have been linked with the 
disease. It is widely accepted that $H$. pylori infection and high salt intake are positively associated with this neoplastic process. Controversial associations have been found with smoking or drinking habits [61]. The three enzymatic sources of NO, nNOS, eNOS, and iNOS, have been characterized in the gastrointestinal tract [62]. There is enhanced expression of iNOS and eNOS in human colorectal cancers [63]. Colon cancer tissue has also been found to express NOS mRNA [64].

Gastric carcinogenesis (GC) is considered as a multistage progressive process. The early indicator for GC predisposition is abnormal hyperproliferation of gastric epithelial cells, such as chronic atrophic gastritis (CAG), dysplasia (DYS) and intestinal metaplasia (IM), which have been considered as precancerous lesions of GC $[65,66]$. In a study by Feng et al., when the lesions progressed from normal to chronic superficial gastritis (CSG),CAG, IM, DYS, and finally to GC, the positive immunostaining rates for p53, iNOS, and VEGF were found to be significantly increased [64]. The study demonstrated that the positive immunostaining rates of iNOS were correlated well with GC lymph node metastasis. All these findings suggested a role of $\mathrm{NO}$ in the initiation and progression of GC. NOS can also deaminate DNA and cause mutations of tumor suppressor genes, and possibly other oncogenes, such as c-met, and initiate genetic alterations of gastric cells leading to gastric malignancy [23].

\section{H.pylori, NO and gastric cancer}

GC may be considered the result of interplay between host genetic profile and environmental toxic agents [67]. The link between $H$. pylori infection and GC has been demonstrated by epidemiological data and in experimental animal models [68-71]. Overproduction of NO via inducible iNOS is suggested to be a significant pathogenic factor in $H$. pylori-induced gastritis [72]. Exposure of gastric epithelial cells to bacterium results in the generation of reactive oxygen species (ROS) and iNOS that, in turn, may cause genetic alterations leading to $\mathrm{GC}$ in a subset of subjects [67].

An increasing frequency of p53 abnormalities occurs as the gastric mucosa progresses from gastritis, through IM, DYS, and early to advanced invasive GC [73]. C to $\mathrm{T}$ mutations in $\mathrm{p} 53$ are induced by $\mathrm{NO}[74,75]$ which might have been produced during $H$. pylori infections. Based on these facts, it can be said that $H$. pylori may lead to GC through overproduction of $\mathrm{NO}$, as one of the mechanisms.

\section{NO in brain tumors}

$\mathrm{NO}$ influences a great variety of vital functions including vascular tone and neurotransmission. $\mathrm{NO}$ emerges as an important mediator of neurotoxicity in a variety of disorders of the central nervous system (CNS). nNOS expression may act as a putative useful indicator of brain tumor differentiation and malignancy [75]. Cobbs et al. examined human brain tumors for three NOS isoforms and NADPH diaphorase, a histochemical marker of NOS activity in the brain. Data of their study suggested that malignant central nervous system neoplasms express unexpectedly high levels of NOS and suggest that NO production may be associated with pathophysiological processes important to these tumors [76].

\section{NO in head and neck cancer}

Oral squamous cell carcinoma (OSCC) is the sixth most common malignancy and a major cause of morbidity and mortality [77]. The high incidence of oral cancer and oral pre-cancer has been linked with habits of tobacco chewing and smoking [78,79]. It is reasonable to assume that components of tobacco, as initiators of inflammatory response, could be responsible for the generation of ROS/RNS that may lead to lipid peroxidation, enhanced NO products, and deranged antioxidant defense system in tobacco users [80]. The damage to genes sustained by elevated ROS/RNS could be one of the mechanisms by which cancer arises in long-term tobacco abuse [80]. Raised levels of $\mathrm{NO}_{2}$ and $\mathrm{NO}_{3}$ were noted in patients with oral pre-cancer $[81,82]$ and in healthy individuals with tobacco habit $[80,81]$. This indicates potential of nitrosative injury in tobacco users and, therefore, NO may have clinical relevance as a biomarker of inflammation and estimation of cancer risk in pre-cancer patients or in healthy tobacco users.

Alcohol intake is related to an increased predisposition to oral cancer [83]. Cooper and Magwere suggested that stimulation of $\mathrm{NO}$ production by ethanol is likely to play an important role in the etiology of some cancers, including head and neck cancer, which preferentially rely on NO signaling [84]. Taken together, these facts implicate the role of NO in development of oral cancer. Very few studies have evaluated the role of NO in oral precancer. Whether NO actually acts as a protumoral agent at a concentration which is present in oral pre-cancer needs further evaluation. Studies are required to know the exact role of $\mathrm{NO}$ in oral pre-cancer which will be helpful in intervening the cancer process.

\section{HPV, NO and head and neck cancer}

The steady increase in the incidence of oropharyngeal cancers over the last four decades has been mainly attributed to oral HPV infection, which has been accepted as an etiological factor for a subset of head and neck squamous cell carcinoma (HNSCC) [85-88]. HPVpositive HNSCCs have a unique risk factor profile. These tumors are more common in younger patients, have a male predominance, and are often staged higher, yet 
have a survival advantage. These patients are less likely to have used tobacco and alcohol excessively [89]. An association between chronic inflammation such as through HPV infection and oral cancer is biologically plausible. It is known that chronic inflammation can lead to the production of NO which in turn can mediate DNA damage. Considering these facts, the role of NO in HPV associated head and neck cancer in patients without habits, needs an evaluation.

\section{Tumoricidal versus tumor promoting effect of NO}

Although several reports have addressed the protumoraleffects of NO, as mentioned above, few have demonstrated the contrasting role of $\mathrm{NO}$ in mediating tumor regression $[9,90,91]$. It has been reported that NO derived from macrophages, Kupffer cells, natural killer cells, and endothelial cells participates in tumoricidal activity against many types of tumors $[90,92]$. These studies suggest that NO has a cytostatic and/or cytotoxic effect on tumor cells (Table 2, Figure 1). Several molecular targets, such as aconitase and ribonucleotidereductase, have been implicated in the cytostatic/cytotoxicity effects mediated by NO. NO has been proposed to cause suppression of DNA synthesis through the salvage pathway [93]. Long standing overproduction of $\mathrm{NO}$ acts as a proapoptotic modulator, activating caspase family proteases through the release of mitochondrial cytochrome $\mathrm{C}$ into the cytosol, upregulation of p53 expression, and alterations in the expression of apoptosis-associated proteins including the Bcl-2 family [24]. A high NO level has been proposed to suppress metastasis [94]. Baritakiet al. have shown that high levels of $\mathrm{NO}$ derived from the NO donor DETA-NONOate inhibits epithelial-mesenchymal transition (EMT) and reverses both the mesenchymal phenotype and the invasive properties of human prostate metastatic cells [95]. Findings of the study by Bonavida et al. have also suggested that NO donors may prove to be potential therapeutic agents in both reversal of drug resistance and the inhibition of EMT and metastasis [96]. Although these tumoricidal roles of $\mathrm{NO}$ have been proposed, most experiments have been performed in vitro $[11,97]$ and such findings have not been reported in cancer patients. It has been suggested that NO concentrations found in OSCC and other solid tumors are insufficient to produce apoptosis [98] and other tumoricidal effect and are likely to facilitate angiogenesis and tumor dissemination [99]. Further, whether NO has an inhibitory or stimulatory effect on the cancer process initially depends on the concentration of $\mathrm{NO}$ achieved and also on other factors such as the type of cell exposed, the redox state, final intracellular concentration, duration of exposure, etc., in the tumor bed. Once the cancer has begun, NO seems to play a protumoral role rather than antitumoralone as the concentration required to cause tumor cell cytotoxicity cannot be achieved by cancer cells [100]. However, considering the cytostatic and/or cytotoxic effects of NO, strategies are being developed to manipulate NO levels in the tumor environment for therapeutic gain.

\section{NO as a novel cancer therapeutic}

NO may exert a biphasic response, such that when NO levels go beyond a critical concentration that would be suitable for tumor growth and survival, growth arrest and/or apoptotic pathways are initiated. These characteristics of NO have been exploited therapeutically with impressive effects in pre-clinical models of cancer to slow tumor growth and to enhance the efficacy of both chemotherapy and radiotherapy [101]. Researchers are investigating various strategies for manipulating in vivo production and exogenous delivery of this molecule, includingiNOS gene therapy, iNOS induction, and administration of NO donor drugs [94] for therapeutic gain.

Transfer of NOS-encoding cDNA sequences into cancer cells for gene therapy purposes was thought to be one of the mechanisms for delivery of NO. However, as both retroviral and adenoviral vectors may be hazardous to the host, cell-based approaches to overcome the problems associated with gene therapy [102] are being sought. Further work into the precise mechanisms of this process is required.

Alternative mechanisms for NO delivery would be the use of NO releasing drugs or NO donors. These are capable of causing sustained release of $\mathrm{NO}$ with a wide range of half-lives, and with predictable estimated doses. They can simultaneously exert a multitude of anticancer activities including enhancement of apoptotic stimuli, inhibition of metastasis, inhibition of angiogenesis, and inhibition of hypoxia, depending on concentration of NO donor and on the cancer type and stage [103].

Several promising findings strongly support the therapeutic application of $\mathrm{NO}$ donors in cancer treatment, used alone or in combination with other subtoxic doses of cytotoxic agents. NO donors have been shown to have the dual function of both sensitizing tumor cells to chemotherapy and immunotherapy and of being involved in the regulation and inhibition of metastasis [104]. NO donors belonging to the class of diazeniumdiolates are promising as they have been shown to be effective chemo- and radio-sensitizing agents along with other attractive properties such as long half-lives and target tissue specific delivery. The role of nitro-glycerine as a chemo-sensitizing agent as demonstrated by Yasuda et al. $[105,106]$, promises a safe and affordable alternative for the management of resistant or metastatic tumors. According to Bonavida and Baritaki [107], NO donors may be considered as novel 
potential therapeutic agents with dual roles in the treatment of patients with refractory cancer and in the prevention of the initiation of the metastatic cascade via EMT.

However, the therapeutic application of NO donors has been limited by potential systemic effects exerted in vivo. These adverse effects include vasodilation leading to pronounced hypotension and accumulation of toxic metabolites such as cyanide [108]. The need to develop the ideal NO donor with maximal antiproliferative properties and minimal side effects has led to the invention of NO-hybrids. NO-hybrids are providing a unique niche in the armamentarium of anticancer agents. Combining NO to existing drugs affords an advantage of adding or potentiating the effects of NO to the benefits of drugs like NSAIDs or statins. NO-drug hybrids such as NO-NSAIDs demonstrate promise as anti-cancer agents and are in clinical trials by NCIsponsored phase I randomized studies (i.e., NO-aspirin in high-risk patients with colorectal cancers) [109].

The synthesis of molecules capable of releasing optimal amounts of $\mathrm{NO}$ at the right time and the right place poses a great challenge to pharmaceutical research. NO donors can be incorporated into or chemically linked to biopolymers, mimicking endogenous NO production at a target site [110,111]. Nanomaterials are currently being harnessed to load high amounts of NO; they are quite stable, are sometimes photoactive, and possess demonstrable biological activity. Their surfaces can also be chemically modified and optimized for specific medical applications. They may facilitate the development of systems for simultaneous therapeutic and diagnostic applications [112]. These nanoparticles can be prepared by physiochemical, chemical, and mechanical methods [113]. However, drug release from particles may vary according to the polymer used or the drug encapsulated [114]. Nanocarriers of NO make the agent more available to systemic circulation and can also enhance the NO target [112].

A small number of reports have been published on the topical delivery of NO using polymeric systems. Kanayama et al. [115] reported that PEGylated polymer micelles may be capable of delivering exogenous NO to tumor cells in a photocontrolled manner, resulting in an NO-mediated antitumor effect, which indicates the promise of this polymeric system in NO-based tumor therapy. Friedman et al. reported that therapeutic levels of NO, in controlled and sustained manner, can be achieved by using combination of glassy matrices and hydrogels [116]. NO-releasing hydrogel/glass hybrid nanoparticles are preferable to other NO-releasing compounds as they depend only on rate of hydration and not on chemical decomposition or enzymatic catalysis [117]. [Ru(Terpy)(bdqi)NO](PF6)3, a NO donor nitrosyl ruthenium complex, has been bound to lipid nanocarriers for topical administration. This system exhibited improved stability in the skin and $\mathrm{NO}$ release by visible light irradiation, with potential applications in the treatment of skin cancer [118]. Stevens et al. engineered NO-releasing SiNPs for NO delivery to human ovarian cancer cells for their inhibition [119]. Another class of liposomes that can be successfully used as nanocarriers are thermosensitive liposomes; they can be employed in the storage, delivery, and active release of $\mathrm{NO}$ in a heat-mediated manner [120]. These thermosensitive liposomes containing NO may have applications in anticancer therapeutics as heat is generated in tumor tissue [121].

Fluorescent nanocrystals, also known as quantum dots (QDs) can be linked to NO-donor molecules. These can specifically lead to effective treatment of large tumors by photodynamic therapy [116-122]. In this case, the nitrosyl compounds can generate, under light application, ROS and NOS via QD excitation, enabling tumor cell death [117-124]. The preliminary in vitro experiments with neuroblastoma cells have demonstrated that the combination of nano-delivery and chemotherapy enhances antitumor activity of chemotherapeutics [125]. Current nanotechnology-based systems are highly promising but there are currently no commercially available nano- or microcarriers for NO delivery. Giles et al. have recently reported the development of two photolabileNO-releasing prodrugs, tert-butyl Snitrosothiol and tert-dodecane S-nitrosothiol. They confirmed that irradiation induced highly significant increase in cytotoxicity in A549 lung carcinoma cells by these drugs. These prodrugs can be further explored to have applications in chemical biology studies and chemotherapy [126]. Thus NO appears to be a potentially promising agent for the treatment of cancer and prevention of metastatic cascade and therefore further studies are required to clearly understand the complex and wide-ranging roles of $\mathrm{NO}$ in order to facilitate its therapeutic use.

\section{Conclusion}

$\mathrm{NO}$ is a relatively stable, free radical gas that readily diffuses into cells and cell membranes where it reacts with molecular targets. The precise reactions of NO depend on the concentration of $\mathrm{NO}$ achieved and on subtle variations in the composition of the intra- and extracellular milieu. NO seems to play a part in various stages of carcinogenesis from initiation to progression. Expression of NOS have been detected in various human cancers. In breast cancer both the development of primary tumor and the process of metastasis seems to be influenced by the presence and amount of NO. In cervical carcinogenesis it acts as a molecular cofactor with HPV infection. 
Exhaled breath analysis and exhaled NO measurement may provide useful assays in providing diagnosis and disease progression in lung cancer. NO can initiate genetic alterations of gastric cells leading to gastric malignancy. Exposure of gastric epithelial cells to $H$. pylori bacterium may result in the generation of ROS and iNOS which in turn may cause genetic alterations leading to GC. Various studies have suggested a role of $\mathrm{NO}$ in the development of head and neck cancer. Thus NO seems to have an important part in the initiation, growth, and metastasis of various cancers. However, it is said to have a tumoricidal role as well. NO has been suggested to have a cytostatic and/or cytotoxic effect on tumor cells. However, this depends on various factors and once the cancer begins, NO seems to play protumoralrather than an antitumoral role. On the other hand, the tumoricidal properties of NO are being utilized in the treatment of cancer. NO can act as a novel potential therapeutic agent in patients with refractory cancer by sensitizing tumor cells to chemotherapy, radiotherapy or immunotherapy. Nevertheless, further validation and experimental/clinical trials are required to develop NO based strategies for cancer prevention and treatment.

\section{Abbreviations}

CAG: Chronic atrophic gastritis; CSG: Chronic superficial gastritis;

DYS: Dysplasia; GC: Gastric cancer; HNSCC: Head and neck squamous cell carcinoma; HPV: Human Papillomaviruses; IM: Intestinal metaplasia;

MMP: Matrix Metalloproteinases; NO: Nitric oxide; NOS: Nitric oxide synthase; eNOS: Endothelial NOS; iNOS: Inducible NOS; QD: Quantum dots; RNS: Reactive nitrogen species; ROS: Reactive oxygen species; TIMP: Tissue inhibitors of MMP; VEGF: Vascular endothelial growth factor.

\section{Competing interests}

The authors declared that they have no competing interests.

\section{Authors' contributions}

SK(C), designed, wrote and drafted the manuscript. MC, SB, ARG, and VJ participated in designing the manuscript and reviewed it. All authors have read and approved the final manuscript.

\section{Author details \\ 'Department of Oral Pathology \& Microbiology, Yerala Dental College and Hospital, Institutional Area, Sector 4, Kharghar, Navi Mumbai, Maharashtra 410 210, India. ${ }^{2}$ Department of Oral Pathology \& Microbiology, Sharad Pawar Dental College, DMIMS, Sawangi(M), Wardha, Maharashatra 442 004, India. ${ }^{3}$ Department of Oral Surgery, Yerala Dental College and Hospital, Institutional Area, Sector 4, Kharghar, Mumbai, Maharashtra 410 210, India.}

Received: 8 January 2013 Accepted: 12 May 2013

Published: 30 May 2013

\section{References}

1. Ignarro LJ, Buga GM, Wood KS, Byrns RE, Chaudhuri G: Endotheliumderived relaxing factor produced and released from artery and vein is nitric oxide. Proc Natl Acad Sci USA 1987, 84:9265-9269.

2. Palmer RMJ, Ferrige AG, Moncada S: Nitric oxide release accounts for the biological activity of endothelial-derived relaxing factor. Nature 1987, 327:524-526.

3. Thomson LL, Lawton FG, Knowles RG, Basley JE, Riversomoreno V, Moncada S: NO synthase activity in human gynecological cancer. Cancer Res 1994, 54:1352-1354
4. Taysi S, Uslu C, Akcay F, Sutbeyaz MY: MDA and nitric oxide in the plasma of patients with advanced laryngeal cancer. Surg Today 2003, 33(9):651-654.

5. Cabs CS, Brenman JE, Aldape KD, Bredt DS, Isrnael MA: Expression of NOS in human central nervous system tumors. Cancer Res 1995, 55:727-730.

6. Reveneau S, Arnould L, Jolimoy G, Hilpert S, Lejeune P, Saint-Giorgio $V$, Belichard C, Jeannin JF: Nitric oxide synthase in human breast cancer is associated with tumor grade, proliferation rate, and expression of progesterone receptor. Lab Invest 1999, 79:1215-1225.

7. Prazma J, Pertrusz P, Mims W, Ball SS, Weissler MC: Immunohistochemical characterization of NOS activity in squamous cell carcinoma of head and neck. Otolaryngol Head Neck Surg 1995, 113:541-549.

8. Ying L, Hofseth $\mathrm{L}$ : An emerging role for endothelial nitric oxide synthase in chronic inflammation and cancer. Cancer Res 2007, 67:1407-1410.

9. Shang ZJ, Li JR, Li ZB: Effects of exogenous nitric oxide on oral squamous cell carcinoma: an in vitro study. J Oral Maxillofac Surg 2002, 60(8):905-910.

10. Harada K, Supriatno, Kawaguchi S, Tomitaro O, Yoshida H, Sato M: Overexpression of iNOS gene suppresses the tumorigenicity and metastasis of oral cancer cells. In Vivo 2004, 18(4):449-455.

11. Moncada S, Palmer RMJ, Higgs EA: Nitric oxide: physiology, pathology, and pharmacology. Pharmacol Rev 1991, 43:109-142.

12. Ambs S, Merriam WG, Ogunfusika MO, Bennett WP, Ishibe N, Hussain SP, Tzeng EE, Geller DA, Billiar TR, Harris CC: p53 and vascular endothelial growth factor regulate tumor growth of NOS2-expressing human carcinoma cells. Nat Med 1998, 12:1371-1376.

13. Grisham MB, Jourd'heuil D, Wink DA: Nitric oxide: I.Physiological chemistry of nitric oxide and its metabolites: implications in inflammation. Gastrointest Liver Physiolo 1 1999, 39:315-321.

14. Kanner J, Harel S, Granit R: Nitric oxide as an antioxidant. Arch Biochem Biophys 1991, 289(1):130-136.

15. Subapriya R, Kumaraguruparan R, Ramachandran CR, Nagini S: Oxidantantioxidant status in patients with oral squamous cell carcinomas at different intraoral sites. Clin Biochem 2002, 35:489-493.

16. Tamir S, Tannenbaum SR: The role of nitric oxide (NO) in the carcinogenic process. Biochim Biophys Acta 1996, 1288:F31-F36.

17. Wink DA, Mitchell JB: The chemical biology of NO. Insights into regulation, protective and toxic mechanisms of nitric oxide. Free Radic Biol Med 1998, 25(4/5):434-456.

18. Patel RP, McAndrew J, Sellak H, White RC, Jo H, Freeman BA, DarleyUsmar VM: Biological aspects of reactive nitrogen species. Biochim Biophys Acta 1999, 1411:385-400.

19. de Rojas-Walker T, Tamir S, Ji H, Wishnok JS, Tannenbaum SR: Nitric oxide induces oxidative damage in addition to deamination in macrophage DNA. Chem Res Toxicol 1995, 8:473-477.

20. Gal A, Wogan GN: Mutagenesis associated with nitric oxide production in transgenic SJL mice. Proc Natl Acad Sci USA 1996, 93:15102-15107.

21. Wink DA, Vodovotz Y, Laval J, Laval F, Dewhirst MW, Mitchell JB: The multifaceted roles of nitric oxide in cancer. Carcinogenesis 1998, 19(5):711-721.

22. Sun Y: Free radicals, antioxidant enzymes and carcinogenesis. Free Radic Biol Med 1990, 8:583-599.

23. Wink DA, Kasprzak KS, Maragos CM, Elespuru RK, Misra M, Dunams TM, Cebula TA, Koch WH, Andrews AW, Allen JS: DNA deaminating ability and genotoxicity of nitric oxide and its progenitors. Science 1992, 254:1001-1003.

24. Choi BM, Pae HO, Jang SI, Kim YM, Chung HT: Nitric oxide as a proapoptotic as well as anti-apoptotic modulator. $J$ Biochem Mol Biol 2002, 35:116-126.

25. Von KA, Brune B: Cyclooxygenase-2: an essential regulator of NOmediated apoptosis. FASEBJ 1997, 11:887-895.

26. Ziche M, Morbidelli L: Nitric oxide and angiogenesis. J Neurooncol 2000, 50:139-148.

27. Lala PK, Orucevic A: Role of nitric oxide in tumor progression: lessons from experimental tumors. Cancer Metastasis Rev 1998, 17:91-106.

28. Breast Cancer Awareness Month in October (World Health Organization 2012). http://www.who.int/cancer/events/breast_cancer_month/en/.

29. Loibl S, von Minckwitz G, Weber S, Sinn HP, Schini-Kerth VB, Lobysheva I, Nepveu F, Wolf G, Strebhardt K, Kaufmann M: Expression of endothelial and inducible nitric oxide synthase in benign and malignant lesions of 
the breast and measurement of nitric oxide using electron paramagnetic resonance spectroscopy. Cancer 2002, 95(6):1191-1198.

30. Alagol H, Erdem E, Sancak B, Turkmen G, Camlibel M, Bugdayci G: Nitric oxide biosynthesis and malondialdehyde levels in advanced breast cancer. Aust N Z J Surg 1999, 69(9):647-650.

31. Thomsen LL, Miles DW, Happerfield L, Bobrow LG, Knowles RG, Moncada S: Nitric oxide synthase activity in human breast cancer. Br J Cancer 1995, 72(1):41-44.

32. Jadeski LC, Hum KO, Chakraborty C, Lala PK: Nitric oxide promotes murine mammary tumour growth and metastasis by stimulating tumour cell migration, invasiveness and angiogenesis. Int J Cancer 2000, 86:30-39.

33. Nakamura Y, Yasuoka H, Tsujimoto M, Yoshidome K, Nakashara M, Nakao K, Nakamura M, Kakudo K: NO in breast cancer: induction of vascular endothelial growth factor- $\mathrm{C}$ and correlation with metastasis and poor prognosis. Clin Cancer Res 2006, 12(4):1201-1207.

34. Switzer $C H$, Cheng RY-S, Ridnour LA, Glynn SA, Ambs S, Wink DA: Ets-1 is a transcriptional mediator of oncogenic nitric oxide signalling in estrogen receptor negative breast cancer. Breast Cancer Res 2012, 14:R125.

35. Tschugguel W, Knogler W, Czerwenka K, Mildner M, Weninger W, Zeillinger $R$, Huber JC: Presence of endothelial calcium-dependent nitric oxide synthase in breast apocrine metaplasia. Br J Cancer 1996, 74:1423-1426.

36. Zeillinger R, Tantscher E, Schneeberger C, Tschugguel W, Eder S, Sliutz G, Huber JC: Simultaneous expression of nitric oxide synthase and estrogen receptor in human breast cancer cell lines. Breast Cancer Res Treat 1996, 40(2):205-207

37. Pance A: Nitric oxide hormones and breast cancer. Nitric oxide and hormones in breast cancer: allies or enemies? Future Oncol 2006, 2(2):275-288.

38. Parkin DM, Bray F, Ferlay J, Pisani P: Global cancer statistics. CA Cancer J Clin 2005, 55:74-108.

39. zur Hausen H: Papillomaviruses and cancer: from basic studies to clinical application. Nat Rev Cancer 2002, 2:342-350.

40. Benencia F, Gamba G, Cavalieri H, Courreges MC, Benedetti R, Villamil SM, Massouh EJ: Nitric oxide and HSV vaginal infection in BALB/c mice. Virology 2003, 309:75-84

41. Carratelli CR, Rizzo A, Paolillo R, Catania MR, Catalanotti P, Rossano F: Effect of nitric oxide on the growth of Chlamydophilapneumoniae. Can J Microbiol 2005, 51(11):941-947.

42. Chang K, Lubo Z: Review article: steroid hormones and uterine vascular adaptation to pregnancy. Reprod Sci 2008, 15:336-348.

43. Naidu MSK, Suryakar AN, Swami SC, Katkam RV, Kumbar KM: Oxidative stress and antioxidant status in cervical cancer patients. Indian J Clin Biochem 2007, 22(2):140-144.

44. Beevi SS, Rasheed MH, Geetha A: Evidence of oxidative and nitrosative stress in patients with cervical squamous cell carcinoma. Clinica Chimica Acta 2007, 375(1-2):119-123.

45. Hiraku Y, Tabata T, Ma N, Murata M, Ding X, Kawanishi S: Nitrative and oxidative DNA damage in cervical intraepithelial neoplasia associated with human papilloma virus infection. Cancer Sci 2007, 98:964-972.

46. Tavares-Murta BM, de Resende AD, Cunha FQ, Murta EFC: Local profile of cytokines and nitric oxide in patients with bacterial vaginosis and cervical intraepithelial neoplasia. Eur J Obstet Gynecol Repro Biol 2008, 138:93-99.

47. Walboomers JMM, Jacobs MV, Manos MM, Bosch FX, Kummer JA, Shah KV, Snijders PJ, Peto J, Meijer CJ, Muñoz N: Human papillomavirus is a necessary cause of invasive cervical cancer worldwide. J Pathol 1999, 189:12-19.

48. Wei L, Gravitt PE, Song H, Maldonado AM, Ozbun MA: Nitric oxide induces early viral transcription coincident with increased DNA damage and mutation rates in human papillomavirus-infected cells. Cancer Res 2009, 69:4878-4884

49. Wei XM, Wang Q, Gao SJ, Sui L: Relationship between nitric oxide in cervical microenvironment and different HPV types and effect on cervical cancer cells. Zhonghua Fu Chan Ke Za Zhi 2011, 46(4):260-265.

50. Mulshine JL, Frank C, Melvyn S, De Luca LM: Lung cancer evolution to preinvasive management. Clin Chest Med 2002, 23(1):1-25.

51. Bilello KS, Murin S, Matthay RA: Epidemiology, etiology, and prevention of lung cancer. Clin Chest Med 2002, 23(1):1-25.

52. Masri FA, Comhair SAA, Koeck T, Xu W, Janocha A, Ghosh S, Dweik RA, Golish J, Kinter M, Stuehr DJ, Erzurum SC, Aulak KS: Abnormalities in nitric oxide and its derivatives in lung cancer. Am J Respir Crit Care Med 2005, 172:597-605.

53. Chen GG, Lee TW, Xu H, Yip JH, Li M, Mok TS, Yim AP: Increased inducible nitric oxide synthase in lung carcinoma of smokers. Cancer 2008, 112(2):372-381.

54. Puhakka AR, Harju TH, Paakko PK, Soini YM, Kinnula VL: Nitric oxide synthases are associated with bronchial dysplasia. Lung Cancer 2006, 51(3):275-282

55. Forbes TA, Hopkins L, Schneider B, Lazarus L, Leitenberg D, Constant S, Schwartz A, Patierno S, Ceryak S: Potential role of nitric oxide in chromium-induced lung carcinogenesis. Cancer Res 2012, 72(8 Suppl):5456. Abstract.

56. Beckman JS, Ischiropoulos H, Zhu L, van der Woerd M, Smith C, Chen J, Harrison J, Martin JC, Tsai M: Kinetics of superoxide dismutaseand iron-catalyzed nitration of phenolics by peroxynitrite. Arch Biochem Biophys 1992, 298:438-445.

57. Haddad IY, Pataki G, Hu P, Galliani C, Beckman JS, Matalon S: Quantitation of nitrotyrosine levels in lung sections of patients and animals with acute lung injury. J Clin Invest 1994, 94:2407-2413.

58. MacMillan-Crow LA, Crow JP, Kerby JD, Beckman JS, Thompson JA: Nitration and inactivation of manganese superoxide dismutase in chronic rejection of human renal allografts. Proc Natl Acad Sci USA 1996, 93:11853-11858.

59. Cobbs CS, Whisenhunt TR, Wesemann DR, Harkins LE, Erwin G, Van M, Minu S: Inactivation of wild-type $p 53$ protein function by reactive oxygen and nitrogen species in malignant gliomacells. Cancer Res 2003, 63:8670-8673.

60. Masri F: Role of nitric oxide and its metabolites as potential markers in lung cancer. Ann Thorac Med 2010, 5(3):123-127.

61. Correa P, Piazuelo MB, Camargo MC: The future of gastric cancer prevention. Gastric Cancer 2004, 7(1):9-16.

62. Calatayud S, Barrachina D, Esplugues JV: Nitric oxide: relation to integrity, injury, and healing of the gastric mucosa. Microsc Res Tech 2001, 53(5):325-335

63. Yagihashi N, Kasajima H, Sugai S, Matsumoto K, Ebina Y, Morita T, Murakami $T$, Yagihashi S: Increased in situ expression of nitric oxide synthase in human colorectal cancer. Virchows Arch 2001, 436(2):109-114.

64. Feng CW, Wang LD, Jiao LH, Liu B, Zheng S, Xie XJ: Expression of p53, inducible nitric oxide synthase and vascular endothelial growth factor in gastric precancerous and cancerous lesions: correlation with clinical features. BMC Cancer 2002, 2:8. 1-7.

65. Correa P: Human gastric carcinogenesis. A multistep and multifactorial process-first American Cancer Society award lecture on cancer epidemiology and prevention. Cancer Res 1992, 52:6735-6740.

66. You WC, Blot WJ, Li JY, Chang YS, Jin ML, Kneller R, Zhang L, Han ZX, Zeng XR, Liu WD, Zhao L, Correa P, Fraumeni JF, Xu GW: Precancerous gastric lesions in a population at high risk of stomach cancer. Cancer Res 1993, 53:1317-1321

67. Nardone G: Review article: Molecular basis of gastric carcinogenesis. Aliment Pharmacol Ther 2003, 17(Suppl. 2):75-81.

68. Parsonnet J, Friedman GD, Oremtreich N, Vogelman H: Risk for gastric cancer in people with CagA positive or CagA negative Helicobacter pylori infection. Gut 1997, 40:297-301.

69. Nomura A, Stemmermann GN, Chyou PH, Kato J, Perez-Perez GI, Blaser MJ: Helicobacter pylori infection and gastric carcinoma among Japanese Americans in Hawaii. N Engl J Med 1991, 325:1132-1136.

70. Watanabe T, Tada M, Nagai H, Sasaki S, Nakao M: Helicobacter pylori infection induces gastric cancer in Mongolian gerbils. Gastroenterol 1998 115(3):642-648.

71. Honda S, Fujioka T, Tokieda M, Satoh R, Nishizono A, Nasu M: Development of Helicobacter pylori-induced gastric carcinoma in Mongolian gerbils. Cancer Res 1998, 58:4255-4259.

72. Nam KT, Oh SY, Ahn B, Kim YB, Jang DD, Yang KH, Hahm KB, Kim DY: Decreased Helicobacter pylori associated gastric carcinogenesis in mice lacking inducible nitric oxide synthase. Gut 2004, 53(9):1250-1255.

73. Fenoglio-Preiser CM, Wang J, Stemmermann GN, Noffsinger A: TP53 and gastric carcinoma: areview. Human Mutat 2003, 21:258-270.

74. Nguyen T, Brunson D, Crespi CL, Penman BW, Wishnok JS, Tannebaum SR: DNA damage and mutation in human cells exposed to nitric oxide in vitro. Proc Natl Acad Sci USA 1992, 89:3030-3034. 
75. Broholm H, Rubin I, Kruse A, Braendstrup O, Schmidt K, Skriver EB, Lauritzen $M$ : Nitric oxide synthase expression and enzymatic activity in human brain tumors. Clin Neuropathol 2003, 22(6):273-281.

76. Cobbs CS, Brenman JE, Aldape KD, Bredt DS, Israel MA: Expression of nitric oxide synthase in human central nervous system tumors. Cancer Res 1995, 55:727-730.

77. Nagpal JK, Das BR: Oral cancer: reviewing the present understanding of its molecular mechanism and exploring the future directions for its effective management. Oral Oncol 2003, 39:213-221.

78. Patel BP, Rawal UM, Rawal RM, Shukla SN, Patel PS: Tobacco, antioxidant enzymes, oxidative stress, and genetic susceptibility in oral cancer. Am J Clin Oncol 2008, 31(5):454-459.

79. Nair U, Bartsch H, Nair J: Alert for an epidemic of oral cancer due to use of the betel quid substitutes gutkha and pan masala: a review of agents and causative mechanisms. Mutagenesis 2004, 19(4):251-262.

80. Rasheed MH, Beevi SS, Geetha A: Enhanced lipid peroxidation and nitric oxide products with deranged antioxidant status in patients with head and neck squamous cell carcinoma. Oral Oncol 2007, 43:333-338.

81. Patel JB, Shah FD, Shukla SN, Shah PM, Patel PS: Role of nitric oxide and antioxidant enzymes in the pathogenesis of oral cancer. JCRT 2009, 5:247-253.

82. Korde SD, Basak A, Chaudhary M, Goyal M, Vagga A: Enhanced nitrosative and oxidative stress with decreased total antioxidant capacity in patients with oral precancer and oral squamous cell carcinoma. Oncology 2011, 80(5-6):382-389.

83. Hashibe M, Brennan P, Benhamou S, Castellsague X, Chen C, Curado MP, Dal Maso L, Daudt AW, Fabianova E, Fernandez L, Wünsch-Filho V Franceschi S, Hayes RB, Herrero R, Koifman S, La Vecchia C, Lazarus P, Levi F, Mates D, Matos E, Menezes A, Muscat J, Eluf-Neto J, Olshan AF, Rudnai P, Schwartz SM, Smith E, Sturgis EM, Szeszenia-Dabrowska N, Talamini R, et al: Alcohol drinking in never users of tobacco, cigarette smoking in never drinkers, and the risk of head and neck cancer: pooled analysis in the International Head and Neck Cancer Epidemiology Consortium. J Natl Cancer Inst 2007, 99(10):777-789.

84. Cooper RG, Magwere T: Nitric oxide-mediated pathogenesis during nicotine and alcohol consumption. Indian J Physiol Pharmacol 2008, 52(1):11-18.

85. Gillison ML, Koch WM, Capone RB, Spafford M, Westra WH, Wu L, Zahurak ML, Daniel RW, Viglione M, Symer DE, Shah KV, Sidransky D: Evidence for a causal association between human papillomavirus and a subset of head and neck cancers. J Natl Cancer Inst 2000, 92(9):709-720.

86. Pintos J, Black MJ, Sadeghi N, Ghadirian P, Zeitouni AG, Viscidi RP Herrero R, Coutlée F, Franco EL: Human papillomavirus infection and oral cancer: a case-control study in Montreal. Canada. Oral Oncol 2008, 44(3):242-250.

87. D'Souza G, Kreimer AR, Viscidi R, Pawlita M, Fakhry C, Koch WM, Westra WH, Gillison ML: Case-control study of human papillomavirus and oropharyngeal cancer. New Engl J Med 2007, 356(19):1944-1956.

88. Joura EA, Leodolter S, Hernandez-Avila M, Wheeler CM, Perez G, Koutsky LA, Garland SM, Harper DM, Tang GW, Ferris DG, Steben M, Jones RW, Bryan J, Taddeo FJ, Bautista OM, Esser MT, Sings HL, Nelson M, Boslego JW, Sattler C, Barr E, Paavonen J: Efficacy of a quadrivalent prophylactic human papillomavirus (types 6, 11, 16, and 18) L1 virus-like-particle vaccine against highgradevulval and vaginal lesions: a combined analysis of three randomised clinical trials. Lancet 2007, 369(9574):1693-1702.

89. Adelstein DJ, Ridge JA, Gillison ML, Chaturvedi AK, D'Souza G, Gravitt PE, Westra W, Psyrri A, Kast WM, Koutsky LA, Giuliano A, Krosnick S, Trotti A, Schuller DE, Forastiere A, Ullmann CD: Head and neck squamous cell cancer and the human papillomavirus: summary of a National Cancer Institute State of the Science Meeting, November 9-10, 2008, Washington, D.C. Head Neck 2009, 31(11):1393-1422.

90. Li LM, Kibourn RG, Adams J, Filder IJ: Role of NO in lysis of tumor cells by cytokine activated endothelial cells. Cancer Res 1991, 51:2531-2535.

91. Shang ZJ, Li JR: Expression of endothelial nitric oxide synthase and vascular endothelial growth factor in oral squamous cell carcinoma: its correlation with angiogenesis and disease progression. J Oral Pathol Med 2005, 4:134-139.

92. Lechner M, Lirk P, Rieder J: Inducible nitric oxide synthase (iNOS) in tumor biology: the two sides of the same coin. Semin Cancer Biol 2005, 15:277-289.
93. Lepoivre M, Flaman JM, Henry Y: Early loss of the tyrosyl radical in ribonucleotidereductase of adenocarcinoma cells producing nitric oxide. J Biol Chem 1992, 267:22994-23000

94. Aranda E, López-Pedrera C, De La Haba-Rodríguez JR, Rodríguez-Ariza A: Nitric oxide and cancer: the emerging role of $\mathrm{S}$ nitrosylation. Curr Mol Med 2012, 12:50-67.

95. Baritaki S, Huerta-Yepez S, Sahakyan A, Karagiannides I, Bakirtzi K, Jazirehi A, Bonavida B: Mechanisms of nitric oxide-mediated inhibition of EMT in cancer: inhibition of the metastasis-inducer Snail and induction of the metastasis-suppressor RKIP. Cell Cycle 2010, 9:4931-4940.

96. Bonavida B: Inhibition of epithelial-to-mesenchymal transition (EMT) in cancer by nitric oxide: pivotal roles of nitrosylation of NF-KB, YY1 and Snail. For Immunopathol Dis Therap 2012, 3(2):125-133.

97. Zhao SF, Tong XY, Zhu FD: Nitric oxide induces oral squamous cell carcinoma cells apoptosis with p53 accumulation. Oral Oncol 2005, 41(8):785-790.

98. Brennan PA, Palacios-Callender M, Umar T, Tant S, Langdon JD: Expression of type 2 nitric oxide synthase and p21 in oral squamous cell carcinoma. Int J Oral Maxillofac Surg 2002, 31(2):200-205.

99. Gallo O, Emanuela M, Lucia M, Franchi A, Fini-storchi I, Vergari WA, Ziche M: Role of NO in angiogenesis and tumor progression in head and neck cancer. J Natl Cancer Inst 1998, 90:587-596.

100. Korde(Choudhari) S, Sridharan G, Gadbail A, Poornima V: Nitric oxide and oral cancer: A review. Oral Oncol 2012, 48:475-483.

101. Singh S, Gupta AK: Mini review nitric oxide: role in tumour biology and iNOS/NO-based anticancer therapies. Cancer Chemother Pharmacol 2011, 67(6):1211-1224.

102. Lehrman S: Virus treatment questioned after gene therapy death. Nature 1991, 401:517-518.

103. Huerta S, Chilka S, Bonavida B: Nitric oxide donors: novel cancer therapeutics (Review). Int J Oncol 2008, 33:909-927.

104. Bonavida B, Baritaki S, Huerta-Yepez S, Vega Ml, Chatterjee D, Yeung K: Novel therapeutic applications of nitric oxide donors in cancer: roles in chemo- and immunosensitization to apoptosis and inhibition of metastases. Nitric oxide 2008, 19(2):152-157.

105. Yasuda H, Yamaya M, Nakayama K, Sasaki T, Ebihara S, Kanda A, Asada M, Inoue D, Suzuki T, Okazaki T, Takahashi H, Yoshida M, Kaneta T, Ishizawa K, Yamanda S, Tomita N, Yamasaki M, Kikuchi A, Kubo H, Sasaki H: Randomized phase II trial comparing nitroglycerin plus vinorelbine and cisplatin with vinorelbine and cisplatin alone in previously untreated stage IIIB/IV non-small-cell lung cancer. J Clin Oncol 2006, 24:688-694.

106. Yasuda H, Nakayama K, Watanabe M, Suzuki S, Fuji H, Okinaga S, Kanda A, Zayasu K, Sasaki T, Asada M, Suzuki T, Yoshida M, Yamanda S, Inoue D, Kaneta T, Kondo T, Takai Y, Sasaki H, Yanagihara K, Yamaya M: Nitroglycerin treatment may enhance chemosensitivity to docetaxel and carboplatin in patients with lung adenocarcinoma. Clin Cancer Res 2006, 12:6748-6757.

107. Bonavida B, Baritaki S: Dual role of NO donors in the reversal of tumor cell resistance and EMT: downregulation of the NF-jB/Snail/YY1/RKIP circuitry. Nitric Oxide 2011, 24(1):1-7.

108. Lee DH, Pfeifer GP: Mutagenesis induced by the nitric oxide donor sodium nitroprusside in mouse cells. Mutagenesis 2007, 22:63-67.

109. Rigas B: Novel agents for cancer prevention based on nitric oxide. Biochem Soc Trans 2007, 35:136-138.

110. Frost MC, Reynolds MM, Meyerhoff ME: Polymers incorporating nitric oxide releasing/generating substances for improved biocompatibility of blood-contacting medical devices. Biomaterials 2005, 26(14):1685-1693.

111. Seabra $A B$, Duran N: Nitric oxide-releasing vehicles for biomedical applications. J Mater Chem 2010, 20(9):1624-1637.

112. Saraiva J, Marotta-Oliveira SS, Cicillini SA, de Oliveira Eloy J, Marchett JM: Nanocarriers for nitric oxide delivery. J Drug Deliv 2011, 1:1-16.

113. Quintanar-Guerrero D, Ganem-Quintanar A, Allemann E, Fessi H, Doelker E: Influence of the stabilizer coating layer on the purification and freezedrying of poly(D, Llactic acid) nanoparticles prepared by an emulsiondiffusion technique. J Microencapsul 1998, 15(1):107-119.

114. Jain R, Shah NH, Malick AW, Rhodes CT: Controlled drug delivery by biodegradable poly(ester) devices: different preparative approaches. Drug Devind Pharm 1998, 24(8):703-727.

115. Kanayama N, Yamaguchi K, Nagasaki Y: PEGylated polymer micelle-based nitric oxide (NO) photodonor with NO-mediated antitumor activity. Chem Lett 2010, 39(9):1008-1009. 
116. Friedman AJ, Han G, Navati MS, Chacko M, Gunther L, Alfieri A, Friedman $J M$ : Sustained release nitric oxide releasing nanoparticles: characterization of a novel delivery platform based on nitrite containing hydrogel/glass composites. Nitric Oxide 2008, 19(1):12-20.

117. Cabrales P, Han G, Roch eC, Nacharaju P, Friedman AJ, Friedman JM: Sustained release nitric oxide from long-lived circulating nanoparticles. Free Radical Bio Med 2010, 49(4):530-538.

118. Marquele-Oliveira F, Santana DC, Taveira SF, Vermeulen DM, de Oliveira AR, da Silva RS, Lopez RF: Development of nitrosyl ruthenium complexloaded lipid carriers for topical administration: improvement in skin stability and in nitric oxide release by visible light irradiation. J Pharm Biomed Anal 2010, 53(4):843-851.

119. Stevens EV, Carpenter AW, Shin JH, Liu J, Der CJ, Schoenfisch MH: Nitric oxide-releasing silica nanoparticle inhibition of ovarian cancer cell growth. Mol Pharmaceutics 2010, 7(3):775-785.

120. Yatvin MB, Weinstein JN, Dennis WH, Blumenthal R: Design of liposomes for enhanced local release of drugs by hyperthermia. Science 1978, 202(4374):1290-1293.

121. Wang J, Teng Y, Hao Y, Oh-Lee J, Mohanty DK: Preparation and properties of polyamines: part llcontrolled and sustained release of nitric oxide (NO) from nitrosated polymers. Polym J 2009, 41(9):715-725.

122. Medintz IL, Uyeda HT, Goldman ER, Mattoussi H: Quantum dot bioconjugates for imaging, labelling and sensing. Nat Mater 2005, 4(6):435-446.

123. Cicillini SA, Prazias ACL, Tedesco AC, Serra OA, da Silva RS: Nitric oxide and singlet oxygen photo-generation by light irradiation in the phototherapeutic window of a nitrosyl ruthenium conjugated with a phthalocyanine rare earth complex. Polyhedron 2009, 28(13):2766-2770.

124. Neuman D, Ostrowski AD, Absalonson RO, Strouse GF, Ford PC: Photosensitized NO release from water soluble nanoparticle assemblies. J Am Chem Soc 2007, 129(14):4146-4147.

125. Hien T, Duong T, Kamarudin ZM, Erlich RB, Li Y, Jones MW, Kavallaris M, Boyer C, Davis TP: Intracellular nitric oxide delivery from stable NOpolymeric nanoparticle carriers. Chem Commun 2013, 49:4190-4192.

126. Giles NM, Kumari S, Gang BP, Yuen CW, Billaud EM, Giles GI: The molecular design of S-nitrosothiols as photodynamic agents for controlled nitric oxide release. Chem Biol Drug Des 2012, 80(3):471-478.

doi:10.1186/1477-7819-11-118

Cite this article as: Korde Choudhari et al: Nitric oxide and cancer: a review. World Journal of Surgical Oncology 2013 11:118.

\section{Submit your next manuscript to BioMed Central and take full advantage of:}

- Convenient online submission

- Thorough peer review

- No space constraints or color figure charges

- Immediate publication on acceptance

- Inclusion in PubMed, CAS, Scopus and Google Scholar

- Research which is freely available for redistribution 